\title{
Implementasi model reflective-metacognitive learning untuk meningkatkan kemampuan berpikir kritis, keterampilan metakognisi dan kesadaran metakognisi
}

\author{
${ }^{1}$ Roniati Sukaisih, ${ }^{2 *}$ Muhali, ${ }^{3}$ Muhammad Asy'ari \\ ${ }^{1}$ Madrasah Aliyah Negeri (MAN) 3 Lombok Tengah \\ ${ }^{2}$ Program Studi Pendidikan Kimia, Universitas Pendidikan Mandalika \\ ${ }^{3}$ Program Studi Pendidikan Olahraga dan Kesehatan, Universitas Pendidikan Mandalika \\ ${ }^{*}$ Correspondence e-mail: muhali@ikipmataram.ac.id
}

\begin{abstract}
Abstrak: Tujuan penelitian ini adalah untuk meningkatkan kemampuan berpikir kritis, keterampilan metakognisi, dan kesadaran metakognisi melalui implementasi model reflective metacognitive learning (RML) dalam pembelajaran fisika di MAN 3 Lombok Tengah. Penelitian ini merupakan penelitian tindakan kelas (PTK) yang dilaksanakan dalam 3 (tiga) siklus pembelajaran dan setiap siklus terdiri dari 3 (tiga) kali pertemuan. Instrumen penelitian ini terdiri dari lembar observasi keterlaksanaan pembelajaran, tes kemampuan berpikir kritis, lembar penilaian keterampilan metakognisi, dan angket kesadaran metakognisi yang telah dinyatakan valid dan reliabel. Pengumpulan data dilakukan dengan teknik observasi, teknik tes, teknik penilaian kinerja, dan teknik angket. Analisis data dilakukan secara deskriptif kuantitatif, dengan menentukan rata-rata dari setiap jenis data, mengkonversi ke dalam skala statistik dan membuat pengkategorisasian. Hasil penelitian menunjukkan bahwa kemampuan berpikir kritis meningkat dari $45 \%$ pada siklus I menjadi $85 \%$ siswa pada siklus II dan III tuntas secara klasikal. Keterampilan metakognisi juga meningkat dari 50\% siswa mencapai kategori baik pada siklus I menjadi $100 \%$ siswa berkategori baik pada siklus II, 75\% dan 25\% siswa mencapai kategori baik dan sangat baik pada siklus III. Hal yang sama pada kesadaran metakognisi meningkat dari $100 \%$ kategori cukup baik pada siklus I menjadi berkategori baik sebesar $100 \%$ pada siklus II dan III. Dengan demikian, model RML dapat diimplementasikan untuk meningkatkan kemampuan berpikir kritis, keterampilan dan kesadaran metakognisi siswa dalam pembelajaran fisika.
\end{abstract}

Kata kunci: berpikir kritis; keterampilan metakognisi; kesadaran metakognisi; reflective metacognitive learning

\section{Implementation of the reflective-metacognitive learning model to improve critical thinking skills, metacognition skills and metacognition awareness}

\begin{abstract}
The purpose of this study was to improve critical thinking skills, metacognition skills, and metacognitive awareness through the implementation of the reflective metacognitive learning (RML) model in physics learning at MAN 3, Central Lombok. This research is a classroom action research (CAR) which is carried out in 3 (three) learning cycles and each cycle consisting of 3 (three) meetings. The research instrument consisted of a learning implementation observation sheet, a critical thinking skills test, a metacognition skill assessment sheet, and a metacognition awareness questionnaire that was declared valid and reliable. The data were collected by means of observation techniques, test techniques, performance appraisal techniques, and questionnaire techniques. Data analysis was carried out in a descriptive quantitative manner, by determining the average of each type of data, converting it into a statistical scale and categorizing it. The results showed that the critical thinking ability increased from $45 \%$ in the first cycle to $85 \%$ of the students in the second and third cycles were classically complete. Metacognition skills also increased from $50 \%$ of students achieving good categories in cycle I to $100 \%$ of students being categorized as good in cycle II, $75 \%$ and $25 \%$ of students achieving good and very good categories in cycle III. The same thing in metacognition awareness increased from $100 \%$ good enough category in cycle I to good category by $100 \%$ in cycle II and III. Thus, the RML model can be implemented to improve students' critical thinking skills, metacognitive skills and awareness in learning physics.
\end{abstract}

Keywords: critical thinking; metacognition skills; metacognition awareness; reflective metacognitive learning

How to Cite: Muhali, M., Sukaisih, R., \& Asy'ari, M. (2020). Implementasi model reflective-metacognitive learning untuk meningkatkan kemampuan berpikir kritis, keterampilan metakognisi dan kesadaran metakognisi. Empiricism Journal, 1(2), 75-95. doi:https://doi.org/10.36312/ej.v1i2.337 


\section{PENDAHULUAN}

Berpikir kritis dan metakognisi merupakan keterampilan esensial yang sangat dibutuhkan siswa dalam penyelesaian masalah pembelajaran dan menjadi tuntutan pembelajaran abad ke-21 (Muhali, 2019). Membelajarkan kedua hal tersebut dapat terintegrasi dalam kegiatan pembelajaran karena memiliki irisan atau keterkaitan yang sangat erat (Asy'ari et al., 2016). Lebih lanjut dijelaskan bahwa irisan antara berpikir kritis dan metakognisi terletak pada: (1) perhatian pada permasalahan yang dihadapi, (2) membelajarkan pemecahan masalah, (3) menekankan refleksi, (4) memberikan kesempatan eksplorasi ide, (5) monitoring, (6) mengevaluasi, (7) manajemen informasi, (8) menekankan pada motivasi internal, dan (9) open mainded (Asy'ari et al., 2016).

Berpikir kritis merupakan kemampuan berpikir tingkat tinggi dengan atribusi dengan analisis, evaluasi, penalaran, berpikir mendalam, dan membuat keputusan (Temel, 2014). Berpikir kritis melibatkan aktivitas belajar seseorang dalam bertanya, apa pertanyaannya, kapan bertanya, bagaimana penalarannya dan kepan menggunakannya, dan metode penalaran yang digunakan (Ismaimuza, 2010). Berpikir kritis memiliki fase-fase yaitu kepekaan, kepedulian, produktivitas, dan reflektif. Kemampuan berpikir kritis dapat dikembangkan melalui serangkaian tahapan yang harus dibelajarkan kepada siswa selama pembelajaran yaitu dengan melibatkan unsur-unsur penting dan mendasar seperti mengidentifikasi, menghubungkan, menganalisis, dan mengevaluasi (Sukaisih et al., 2020).

Metakognisi merupakan transaksi kognitif dengan sesame atau lingkunagn belajar, berbagai aktivitas pemrosesan informasi dalam pencapaian tujuan (Flavell (1976). Konsep metakognisi sebagai aktivitas berpikir tentang pemikiran diri dan orang lain, memonitor dan mengatur jalannya pemikiran diri (Kluwe, 1982). Schraw \& Dennison (1994) menjelaskan metakognisi sebagai sebuah aktivitas kesadaran akan pengetahuan tentang kognisi seseorang dengan melibatkan regulasi dalam aktivitas kognitifnya. McCormick (2003) menekankan konsep metakognisi pada pengetahuan tentang bagaimana belajar seseorang. Lai (2011) menyebutkan metakognisi sebagai berpikir tentang berpikir yang meliputi pengetahuan dan regulasinya. Metakognisi sangat penting dalam pembelajaran karena harus dilakukan sebelum, selama, dan setelah pembelajaran (Ya-Hui, 2012). Metakognisi merupakan serangkaian proses memperoleh pengetahuan melalui keterampilan tertentu yang secara sadar dilakukan oleh siswa selama pembelajaran (Muhali, 2018; Muhali et al., 2019).

Membelajarkan metakognisi kepada siswa dirasakan sebagai hal yang paling sulit dilakukan mengingat konsep kesadaran pada diri siswa menjadi faktor utama yang harus diperhatikan dalam melatihnya. Pembelajaran berlangsung secara alami tanpa ada interfensi dari guru, walaupun ada tetapi hanya sedikit memfasilitasi dan sifatnya mengarahkan siswa dalam melaksanakan proses belajarnya. Siswa dihadapkan pada situasi belajar yang alami/natural misalnya dalam menentukan tujuan belajar untuk mencapai kompetensi tertentu, kebutuhan belajar (sumber yang dibutuhkan), pemanfaatan sumber belajar (termasuk kemampuan menganalisis materi yang dibutuhkan), membuat rencana belajar, melaksanakan rencana, memonitor dan mengevaluasi setiap proses belajar serta memprbaiki proses/strategi yang dianggap kurang sesuai dalam menyelesaikan masalah.

Pembelajaran fisika kebanyakan didominasi oleh penyajian pengetahuan jadi, banyak membahas fakta dan hukum (Verawati et al., 2013), sehingga seringkali siswa sebagai objek penerima (Prayogi et al., 2013), kemampuan guru dalam pengelolaan kelas masih terbatas, pencapaian konten pembelajaran yang ditarget oleh waktu, jumlah siswa setiap kelas yang terlalu banyak, variasi dalam pemilihan model pembelajaran juga menjadi masalah dalam pembelajaran fisika (Bahtiar et al., 2014), sehingga melatih siswa dalam belajar dengan menanamkan kemampuan berpikir kritis dan metakognisi menjadi kesulitan bagi kebanyak para guru. Hal tersebut menyebabkan siswa mengalami kesulitan dalam pembelajaran fisika khususnya dalam memecahkan permasalahan berupa soal-soal yang disajikan dan hal ini terjadi secara merata pada konsep fisika yang dibelajarkan. Menurut Azizah et al. (2015), kesulitan tersebut disebabkan kurang maksimalnya pembelajaran kepada siswa dalam bentuk hands on activity, sebanyak $88 \%$ dari 120 siswa menyatakan bahwa pembelajaran fisika yang sering dialami adalah metode ceramah. Lebih lanjut Azizah et al. (2015) menyatakan sebanyak $32 \%$ siswa kesulitan menyelesaikan permasalahan pada soal, $26 \%$ siswa kesulitan 
memahami konsep dan rumus, $18 \%$ kesulitan menggunakan persamaan atau rumus dalam penyelesaian masalah, 17\% kesulitan menganalisis grafik atau gambar, dan 7\% 7\% kesulitan menyimpulkan materi yang telah dipelajari. Gutulo dan Tekello (2015) dalam studinya menemukan bahwa: (1) sebagian besar siswa (48,45\%) memiliki minat sedang, 13,36\% siswa sangat minat dengan fisika, dan sisanya sangat tidak berminat dalam belajar fisika, (2) sebagian besar siswa memiliki praktik kerja kelompok yang rendah dan beberapa siswa dengan praktik kerja kelompok yang buruk dan sangat buruk, hal ini member jawaban akan kurangnya inisiasi guru untuk berpartisipasi dalam kerja kelompok, (3) sebagian besar siswa tidak mendapatkan bahan referensi yang memadai di perpustakaan sehingga sebagian besar siswa terkadang menggunakan perpustakaan, (4) teknik penilaian yang diterapkan guru dalam mengevaluasi kinerja berdasarkan ujian tengah semester dan akhir, selain itu terkadang guru fisika memberikan tugas kelas dan pekerjaan rumah untuk masing-masing siswa, (5) sebanyak $78,03 \%$ dan $21,97 \%$ ) siswa menyatakan bahwa guru fisika di kelas tidak pernah dan jarang menggunakan laboratorium untuk praktikum, alasan utamanya adalah kurangnya minat guru fisika dan kurangnya peralatan di laboratorium, (6) guru fisika mayoritas $(81,13 \%)$ tidak menghadiri kegiatan pengembangan professional dalam bentuk workshop, seminar, diskusi panel, dan lain sebagainya, namun ada kebiasaan saling berbagi pengalaman dan kerja sama antar guru fisika di sekolah. Kenyataan ini memberi penguatan akan sulitnya melatih kemampuan berpikir kritis dan metakognisi secara utuh dan terintegrasi dalam pembelajaran. Dengan demikian, sesuai fenomena tersebut maka perlu secara terus menerus untuk mencari dan menemukan upaya memperbaiki kinerja dan kualitas pembelajaran bagi guru.

Berbagai upaya untuk memperbaiki kinerja dan kualitas proses dan hasil pembelajaran fisika telah diupayakan oleh banyak peneliti. Hasil studi yang telah dilakukan oleh Sukaisih \& Muhali (2013) menerapkan pembelajaran problem solving dalam memperbaiki hail belajar dan kesadaran metakognisi siswa pada materi suhu dan kalor. Hasil yang diperoleh menunjukkan peningkatan kesadaran metakognisi siswa setelah dibelajarkan dalam 3 (tiga) siklus pembelajaran dan peningkatan yang dicapai sebesar $77,14 \%$ siswa dengan kategori baik dan sangat baik dan sebesar $22,86 \%$ siswa dengan kategori cukup dan rendah. Secara klasikal penelitian ini belum mampu mencapai persentase kesadaran siswa sampai $85 \%$ sehingga siswa perlu dilatih terutama agar lebih sadar dalam melakukan regulasi kognisi (planning, information management, monitoring, debugging, dan evaluation) dalam pemecahan masalah. Sukaisih et al. (2020) yang menerapkan pembelajaran dengan model pemecahan masalah dengan strategi konflik kognitif untuk meningkatkan keterampilan berpikir kritis dan metakognisi. Hasil studi ini menunjukkan bahwa: (1) keterampilan berpikir kritis siswa masih lemah pada indikator mengevaluasi, menganalisis dan menghubungkan dilihat dari hasil evaluasi menggunakan soal-soal terkait indikator tersebut, (2) keterampilan berpikir kritis, indikator yang paling sulit dilatihkan adalah memeriksa proses pelaksanaan perencanaan, dan mengevaluasi hasil, dengan pencapaian selama 3 (tiga) siklus pembelajaran dengan kategori cukup. Hapsari dan Widodo (2016) telah membelajarkan pengetahuan dan keterampilan metakognisi siswa menggunakan bahan ajar berbasis konstruktivismetakognitif, hasil diperoleh bahwa peningkatan pengetahuan dan keterampilan mencapai $\mathrm{N}$ Gain = 0,57 dengan kategori sedang. Lebih lanjut Hapsari dan Widodo (2016) menyatakan bahwa dalam mengajarkan siswa, sebaiknya mempertimbangkan pemberian motivasi dan kesadaran akan tujuan belajar yang harus dicapai sehingga dapat mendorong siswa untuk melibatkan pengetahuan dan keterampilan metakognisi dalam proses pembelajaran. Berdasarkan kajian hasil penelitian tersebut maka perlu diupayakan strategi yang dapat menumbuhkan kesadaran akan tujuan belajar siswa agar pengetahuan dan metakognisi lebih dilibatkan secara maksimal, terutama terkait dengan kemampuan siswa dalam memeriksa dan mengevaluasi proses penyelesaian masalah.

Model RML telah dikembangkan untuk membelajarkan kemampuan metakognisi siswa, kemampuan yang dimaksud meliputi pengetahuan metakognisi, keterampilan metakognisi, dan kesadaran metakognisi (Muhali, 2018). Model ini menitik beratkan pada strategi-strategi yang memberikan kesempatan kepada siswa untuk merefleksikan pembelajarannya sebagai kegiatan akhir pada setiap fase/tahap pembelajaran, yaitu melalui (1) fenomena konflik 
kognitif, (2) fenomena anomali, (3) proses internalisasi, dan (4) fenomena baru yang masih terkait. Secara empiris model ini telah terbukti efektif untuk meningkatkan kemampuan metakognisi siswa (Muhali et al., 2019). Dengan demikian, pada penelitian ini model RML dijadikan sebagai solusi model yang digunakan dalam pembelajaran untuk meningkatkan kemampuan berpikir kritis, keterampilan metakognisi, dan kesadaran metakognisi. Fase dan kegiatan model RML selengkapnya seperti tercantum pada Tabel 1 sebagai berikut.

Tabel 1. Fase dan Kegiatan Pembelajaran dengan Model RML (Muhali, 2018; 2018b).

\begin{tabular}{ccc}
$\begin{array}{c}\text { Fase/Tahap Model } \\
\text { RML }\end{array}$ & Kegiatan Pembelajaran & $\begin{array}{c}\text { Aplikasi dalam Kegiatan } \\
\text { Pembelajaran }\end{array}$ \\
\hline
\end{tabular}

\begin{tabular}{lrl}
\hline $\begin{array}{l}\text { Fase 1, refleksi } \\
\text { oroientasi yaitu } \\
\text { strategi yang }\end{array}$ & 1. $\begin{array}{l}\text { Penyampaian tujuan } \\
\text { pembelajaran. }\end{array}$ \\
$\begin{array}{l}\text { diperlukan untuk } \\
\text { menilai dan }\end{array}$ & $\begin{array}{l}\text { 2. } \\
\text { mengerti/memahamisis informasi dan } \\
\text { kondisi. }\end{array}$
\end{tabular}

permasalahan.

Fase 2, refleksi

organisasi yaitu

melakukan

identifikasi sasaran

dan tujuan utama,

perencanaan

khusus yang

diperlukan untuk

menyenyelesaikan

rencana umum
3. Menilai kefamiliaran dengan tugas.

4. Menilai tingkat kesulitan permasalahan dan peluang untuk berhasil menyelesaikan masalah.

5. Refleksi kegiatan melalui penyajian fenomena konflik kognitif untuk mengaktifkan pengetahuan awal siswa.

1. Identifikasi sub tujuan dan tujuan akhir pembelajaran.

2. Membuat perencanaan khusus dan umum.

3. Mengorganisasi data.
- Menyampaikan tujuan pembelajaran secara umum.

- Meminta siswa membaca informasi dari sumber belajar yang relevan.

- Bertanya kepada siswa tentang materi yang dipelajari.

- Menanyakan kembali pada siswa permasalahan yang umum pembelajaran.

- Menyajikan fenomena konflik kognitif untuk menggali dan mengaktifkan pengetahuan awal siswa.

- Meminta siswa mengidentifikasi sub tujuan yang menjadi prasyarat yang harus diketahui terlebih dahulu untuk mencapai tujuan utama/akhir.

- Membuat perencanaan langkah-langkah pemecahan masalah umum yang telah diidentifikasi pada fase 1 orientasi, yang selanjutnya diturunkan menjadi perencanaan untuk mencapai sub tujuan.

- Membagi siswa ke dalam kelompok.

- Mengarahkan siswa dalam merumuskan hipotesis, mendefinisikan secara operasional variabel-variabel dalam pembelajaran, penentuan langkah-langkah pemecahan masalah yang akan digunakan.

4. Refleksi melalui penyajian fenomena anomali yang memungkinkan siswa
- Refleksi kegiatan pada fase refleksi organisasi dengan penyajian fenomena anomali 


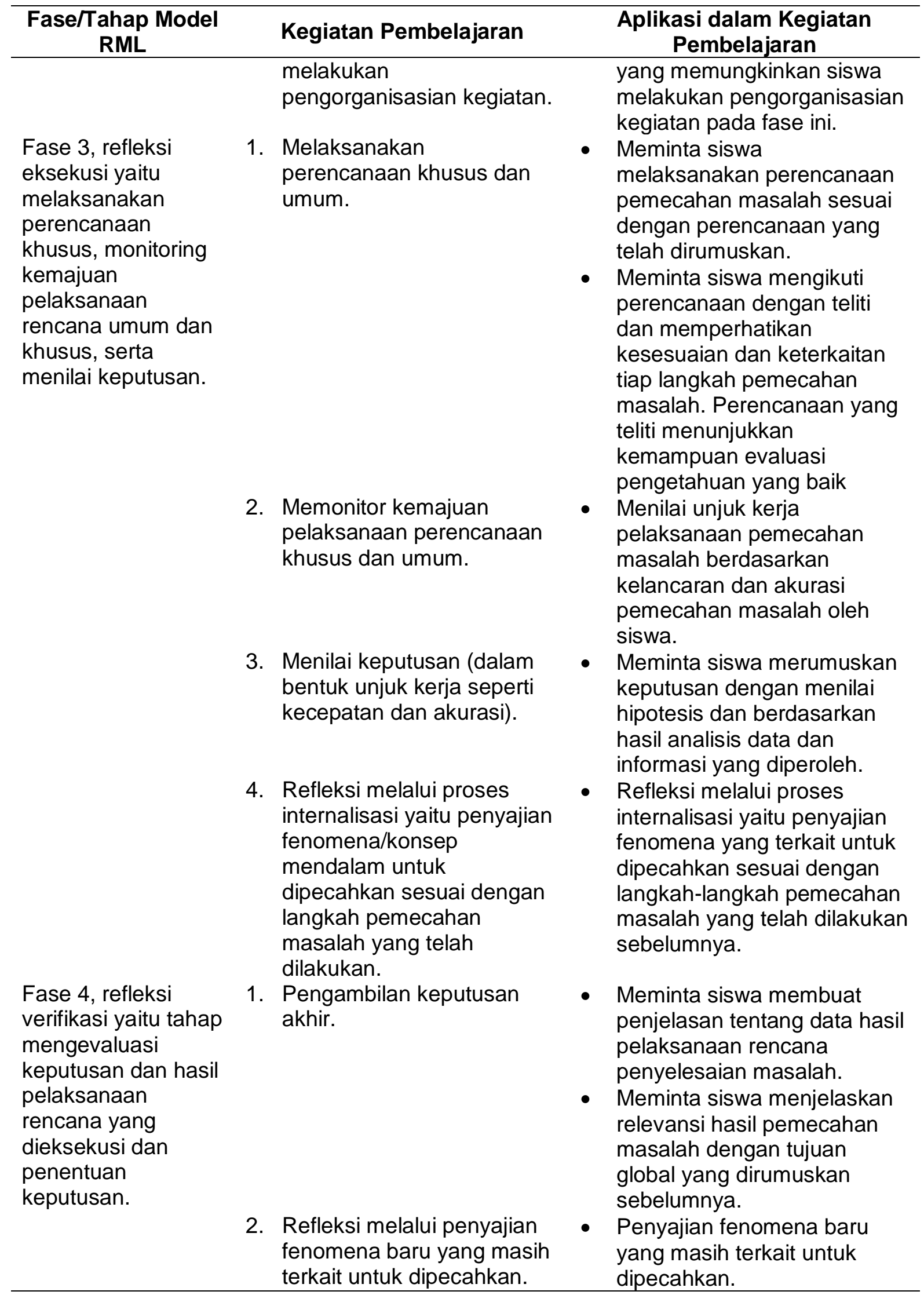

Berdasarkan uraian tersebut di atas, maka rumusan permasalahan dalam penelitian ini adalah apakah penerapam model RML dalam pembelajaran fisika dapat meningkatkan kemampuan berpikir kritis, keterampilan metakognisi, dan kesadaran metakognisi siswa di 
kelas X MAN 3 Lombok Tengah tahun pelajaran 2020/2021? Sesuai rumusan masalah tersebut maka tujuan yang akan dicapai pada penelitian ini adalah untuk meningkatkan kemampuan berpikir kritis, keterampilan metakognisi, dan kesadaran metakognisi siswa melalui penerapan model RML dalam pembelajaran fisika MAN 3 Lombok Tengah.

\section{METODE}

Jenis penelitian ini adalah PTK (Penelitian Tindakan Kelas). PTK merupakan jenis penelitian yang ditandai dengan siklus dengan 4 (empat) tahap kegiatan, yaitu tahap perencanaan, pelaksanaan tindakan, observasi dan evaluasi, dan refleksi. PTK merupakan sebuah upaya untuk memperbaiki kinerja pembelajaran kepada kelompok siswa yang mengalami kesulitan belajar dan belum mencapai ketuntasan belajar secara klasikal (85\% siswa dengan hasil belajar di atas kriteria ketuntasan minimal).

Penelitian ini dilakukan dalam 3 (tiga) siklus dengan 3 (tiga) kali pertemuan untuk setiap siklus pembelajaran. Deskripsi rincian kegiatan dari setiap tahapan dalam penelitian ini dapat dijelaskan sebagai berikut.

1. Tahap perencanaan

Kegiatan yang dilakukan pada tahap perencanaan meliputi: (1) menyusun silabus dan RPP (rencana pelaksanaan pembelajaran) berbasis model RML. (2) menyusun LKS (Lembar Kegiatan Siswa) untuk setiap pertemuan, (3) membuat instrumen berupa lembar keterlaksanaan pembelajaran, tes kemampuan berpikir kritis, lembar penilaian keterampilan metakognisi, dan menyiapkan angket kesadaran metakognisi selama pembelajaran.

2. Tahap pelaksanaan tindakan

Kegiatan pada tahap pelaksanaan tindakan meliputi: (1) melaksanakan pembelajaran sesuai RPP yang telah dirancang, dan (2) pengamatan proses pembelajaran oleh teman sejawat untuk mengamati keterlaksanaan pembelajaran sesuai RPP berbasis model RML.

3. Tahap observasi dan evaluasi

Kegiatan yang dilakukan pada tahap observasi dan evaluasi meliputi: (1) kegiatan mengobservasi keterlaksanaan pembelajaran oleh teman sejawat, (2) mengevaluasi kemampuan berpikir kritis siswa pada akhir pertemuan di setiap siklus, (3) melakukan evaluasi keterampilan metakognisi siswa selama pembelajaran yang dilakukan oleh observer, dan (4) melakukan evaluasi hasil pengisian angket kesadaran metakognisi siswa.

4. Tahap refleksi

Kegiatan yang dilakukan pada tahap refleksi yaitu melakukan peninjauan kembali kesesuaian perencanaan dengan pelaksanaannya, melihat pencapaian hasil evaluasi kemampuan berpikir kritis, melihat hasil penilaian keterampilan metakognisi, dan melihat hasil pengisian angket kesadaran metakognisi siswa.

Semua kegiatan pada setiap tahap penelitian tersebut di atas secara singkat dapat dirancang atau didesain seperti disajikan pada Gambar 1 di bawah ini.

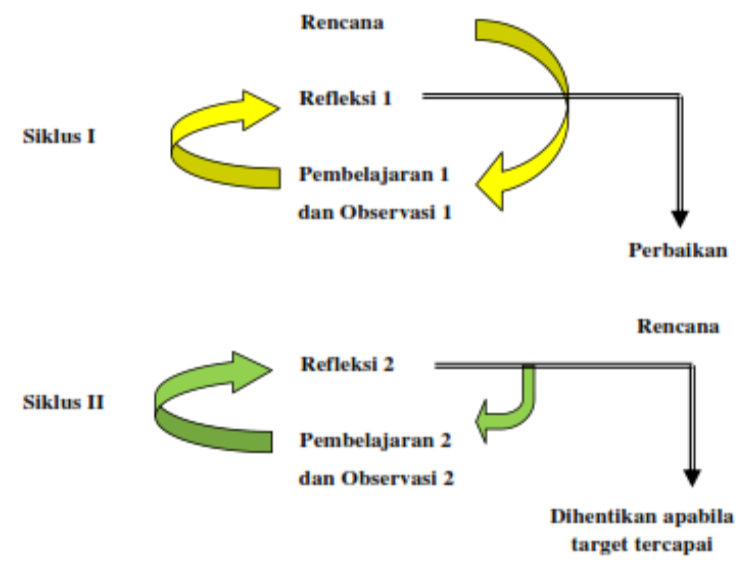

Gambar 1. Alur penelitian tindakan kelas menurut Kemmis \& Mc. Taggart (Sukaisih et al., 2020) 
Subyek penelitian ini adalah siswa kelas X tahun pelajaran 2020/2021 dengan jumlah siswa 20 orang. Instrumen yang digunakan berupa: (1) lembar observasi keterlaksanaan pembelajaran, (2) tes kemampuan berpikir kritis, (3) lembar penilaian keterampilan metakognisi siswa, dan (4) angket kesadaran metakognisi. Instrumen lembar observasi keterlaksanaan pembelajaran mencakup serangkaian kegiatan yang tercantum dalam RPP berbasis model RML, dengan materi yang dibelajarkan adalah kerak lurus. Materi siklus I meliputi: (1) mengamati dan mengidentifikasi benda di sekitar yang bergerak lurus, (2) menentukan perpindahan, jarak, kecepatan dan laju. Materi siklus II: (1) menentukan percepatan dan perlambatan benda bergerak, (2) mengidentifikasi besaran dalam gerak lurus beraturan. Materi siklus III: (1) mengidentifikasi besaran-besaran dalam berak lurus berubah beraturan, (2) mengamati gerak jatuh bebas dan gerak vertical ke atas. Instrumen tes kemampuan berpikir kritis terdiri dari 4 (empat) soal uraian pada setiap siklus yang memenuhi indikator mengidentifikasi, menghubungkan, menganalisis, dan mengevaluasi seperti yang telah dilakukan pada penelitian sebelumnya (Sukaisih et al., 2020). Instrumen lembar penilaian keterampilan metakognisi yang digunakan pada penelitian ini adalah instrumen yang dikembangkan oleh Muhali (2018), Muhali et al. (2019) yang meliputi 8 (delapan) aspek di yaitu: (1) perumusan tujuan umum pembelajaran maupun khusus, (2) merumuskan rumusan masalah dan hipotesis, (3) membuat perencanaan pemecahan masalah, (4) melaksanakan perencanaan secara sistematis, (5) mengamati proses pelaksanaan perencanaan secara kelompok dan individu, (6) memeriksa proses pelaksanaan perencanaan secara kelompok dan individu, (7) mencatat atau mengumpulkan data, dan (8) mengevaluasi hasil. Instrumen angket kesadaran metakognisi yang digunakan adalah instrumen MAI (Metacognitive Awarreness Inventori) menurut Schraw \& Dennison (1994) yang telah diadaptasi dan diuji coba oleh Muhali et al. (2019) yang terdiri dari 52 butir pertanyaan/pernyataan dengan 8 (delapan) indikator yaitu: (1) declarative knowledge, (2) procedural knowledge, (3) conditional knowledge, (4) planning, (5) information management strategy, (6) monitoring, (7) debugging, dan (8) evaluation.

Instrumen lembar observasi keterlaksanaan pembelajaran, lembar penilaian keterampilan metakognisi, dan angket kesadaran metakognisi yang digunakan telah dinyatakan valid dan reliabel menurut hasil ujicoba yang dilakukan oleh Muhali et al. (2019), sedangkan instrumen kemampuan berpikir kritis siswa dilakukan melalui penilaian 3 (tiga) orang validator dari dosen FSTT Universitas Pendidikan Mandalika. Penentuan nilai validitas instrumen $\left(r_{a}\right)$ ditentukan dari ukuran tunggal koefesien korelasi antar penilai, sedangkan penilaian reliabilitas instrument ditentukan dari perhitungan ukuran rata-rata koefesien korelasi antar penilai (Cronbach's Alpha, a), dengan persamaan sebagi berikut (Malhotra, 2011).

$$
r_{\alpha}=\frac{[(\text { Average Square people }- \text { Average Square residual }]}{[\text { Average Square people }+(k-1) \text { Average Square residual })]}
$$

Keterangan: $k=$ banyaknya butir

$$
\propto=\frac{k r_{\propto}}{\left[1+(k-1) r_{\propto}\right]}
$$

Kriteria penentuan validitas dan reliabilitas instrumen penelitian setelah divalidasi merujuk pada kriteria seperti tercantum dalam Tabel 2 sebagai berikut.

Tabel 2. Kriteria Validitas dan Reliabilitas Instrumen Penelitian

\begin{tabular}{ccc}
\hline Pengujian & Skala Statistik & Kategori \\
\hline Validitas & $r_{\propto} \leq r_{\text {tabel }}$ & Tidak valid \\
& $r_{\propto}>r_{\text {tabel }}$ & Valid \\
Reliabilitas & $\propto<0,6$ & Tidak reliabel \\
& $0,6 \leq \propto \leq 1,0$ & Reliabel \\
\hline
\end{tabular}

Hasil perhitungan nilai validitas instrumen lembar observasi keterlaksanaan pembelajaran, lembar penilaian keterampilan metakognisi, dan angket kesadaran metakognisi tercantum pada Tabel 3 , sedangkan hasil perhitungan validitas instrumen 
kemampuan berpikir kritis pada siklus I, II, dan III disajikan pada Tabel 4, Tabel 5, dan Tabel 6 sebagai berikut.

Tabel 3. Validitas Instrumen Keterlaksanaan Pembelajaran, Keterampilan dan Kesadaran Metakognisi

\begin{tabular}{|c|c|c|c|c|c|c|c|c|c|}
\hline \multirow{2}{*}{ No. } & \multirow{2}{*}{ Instrumen yang Dinilai } & \multirow{2}{*}{$\mathbf{N}$} & \multicolumn{6}{|c|}{ Validitas $\left(r_{\alpha}\right)$} & \multirow[b]{2}{*}{$\mathbf{r}_{\text {tab }}$} \\
\hline & & & Isi & (a) & Konstruk & (a) & Muka & (a) & \\
\hline 1. & & 16 & 0,751 & 0,858 & & 0,849 & 0,815 & 0,898 & 7 \\
\hline 2. & Lembar penilaia & 14 & 0,7 & 0,884 & & 0 & 1 & 0,947 & 0,532 \\
\hline 3. & Angket kesadaran metakognisi & 17 & 0,751 & 0,858 & 0,871 & 0,931 & 0,760 & 0,864 & 0,483 \\
\hline
\end{tabular}

Tabel 4. Validitas Instrumen Kemampuan Berpikir Kritis Siswa Siklus I Sesuai Penilaian Validator

\begin{tabular}{|c|c|c|c|c|c|c|c|c|c|c|}
\hline \multirow{3}{*}{$\begin{array}{l}\text { No. } \\
\text { Soal }\end{array}$} & \multicolumn{10}{|c|}{ Aspek yang Dinilai } \\
\hline & \multicolumn{3}{|c|}{ Validasi Isi } & \multirow{2}{*}{$\begin{array}{c}\text { Rata- } \\
\text { rata }\end{array}$} & \multirow{2}{*}{ Kategori } & \multicolumn{3}{|c|}{ Validasi Isi } & \multirow{2}{*}{$\begin{array}{l}\text { Rata- } \\
\text { rata }\end{array}$} & \multirow{2}{*}{ Kategori } \\
\hline & V1 & V2 & V3 & & & V1 & V2 & V3 & & \\
\hline 1 & 3 & 4 & 3 & 3,33 & V & 4 & 4 & 4 & 4,00 & SV \\
\hline 2 & 4 & 3 & 4 & 3,67 & SV & 4 & 3 & 4 & 3,67 & SV \\
\hline 3 & 3 & 3 & 3 & 3,00 & V & 4 & 4 & 3 & 3,67 & SV \\
\hline 4 & 4 & 3 & 4 & 3,67 & SV & 4 & 3 & 4 & 3,67 & SV \\
\hline
\end{tabular}

Keterangan: V1 = validator kesatu, V2 = validator kedua, dan V3 = validator ketiga

Tabel 5. Validitas Instrumen Kemampuan Berpikir Kritis Siswa Siklus II Sesuai Penilaian Validator

\begin{tabular}{|c|c|c|c|c|c|c|c|c|c|c|}
\hline \multirow{3}{*}{$\begin{array}{l}\text { No. } \\
\text { Soal }\end{array}$} & \multicolumn{10}{|c|}{ Aspek yang Dinilai } \\
\hline & \multicolumn{3}{|c|}{ Validasi Isi } & \multirow{2}{*}{$\begin{array}{c}\text { Rata- } \\
\text { rata }\end{array}$} & \multirow{2}{*}{ Kategori } & \multicolumn{3}{|c|}{ Validasi Isi } & \multirow{2}{*}{$\begin{array}{l}\text { Rata- } \\
\text { rata }\end{array}$} & \multirow{2}{*}{ Kategori } \\
\hline & V1 & V2 & V3 & & & V1 & V2 & V3 & & \\
\hline 1 & 3 & 4 & 3 & 3,33 & $\mathrm{~V}$ & 3 & 4 & 4 & 3,67 & SV \\
\hline 2 & 3 & 3 & 4 & 3,33 & V & 4 & 4 & 4 & 4,00 & SV \\
\hline 3 & 3 & 4 & 3 & 3,33 & V & 3 & 4 & 4 & 3,67 & SV \\
\hline 4 & 4 & 3 & 4 & 3,67 & SV & 4 & 3 & 4 & 3,67 & SV \\
\hline
\end{tabular}

Keterangan: V1 = validator kesatu, V2 = validator kedua, dan V3 = validator ketiga.

Tabel 6. Validitas Instrumen Kemampuan Berpikir Kritis Siswa Siklus III Sesuai Penilaian Validator

\begin{tabular}{|c|c|c|c|c|c|c|c|c|c|c|}
\hline \multirow{3}{*}{$\begin{array}{l}\text { No. } \\
\text { Soal }\end{array}$} & \multicolumn{10}{|c|}{ Aspek yang Dinilai } \\
\hline & \multicolumn{3}{|c|}{ Validasi Isi } & \multirow{2}{*}{$\begin{array}{l}\text { Rata- } \\
\text { rata }\end{array}$} & \multirow{2}{*}{ Kategori } & \multicolumn{3}{|c|}{ Validasi Isi } & \multirow{2}{*}{$\begin{array}{l}\text { Rata- } \\
\text { rata }\end{array}$} & \multirow{2}{*}{ Kategori } \\
\hline & V1 & V2 & V3 & & & V1 & V2 & V3 & & \\
\hline 1 & 4 & 4 & 3 & 3,67 & SV & 4 & 4 & 4 & 4,00 & SV \\
\hline 2 & 4 & 3 & 4 & 3,67 & SV & 4 & 3 & 4 & 3,67 & SV \\
\hline 3 & 4 & 4 & 3 & 3,67 & SV & 4 & 4 & 4 & 4,00 & SV \\
\hline 4 & 4 & 3 & 4 & 3,67 & SV & 4 & 3 & 4 & 3,67 & SV \\
\hline
\end{tabular}

Keterangan: V1 = validator kesatu, V2 = validator kedua, dan V3 = validator ketiga.

Berdasarkan data pada Tabel 3 di atas menunjukkan bahwa instrumen lembar keterlaksanaan pembelajaran dinyatakan valid dan reliabel secara isi (content), konstruk (construct) dan muka (face) serta dengan nilai $r_{a}=0,751 ; 0,739 ; 0,815$ lebih besar dari $r_{\text {tabel }}=$ 0,497, dan nilai Cronbach's Alpha, $\mathrm{a}=0,858 ; 0,849 ; 0,898$. Instrumen lembar penilaian keterampilan metakognisi memiliki nilai $r_{a}=0,793 ; 0,840 ; 0,901$ lebih besar dari $r_{\text {tabel }}=0,532$, dan nilai Cronbach's Alpha, $\mathrm{a}=0,884 ; 0,913 ; 0,947$ sehingga dinyatakan valid dan reliabel. Instrumen angket kesadaran metakognisi memiliki nilai $r_{a}=0,751 ; 0,871 ; 0,931$ lebih besar dari $r_{\text {tabel }}=0,483$, dan nilai Cronbach's Alpha, $a=0,858 ; 0,931 ; 0,864$ sehingga dinyatakan valid dan reliabel. Dengan demikian, instrument tersebut dapat digunakan untuk mengukur keterlaksanaan pembelajaran, keterampilan metakognisi, dan kesadaran metakognisi siswa yang dibelajarkan dengan model RML. Data pada Tabel 4, Tabel 5, dan Tabel 6 menunjukkan bahwa semua soal instrument yang digunakan untuk mengukur kemampuan berpikir kritis 
pada setiap siklus pembelajaran dinyatakan valid baik secara isi maupun secara bahasa dan penulisan soal.

Teknik pengumpulan dan analisis data pada penelitian ini adalah sebagai berikut.

1. Teknik observasi

Teknik ini dilakukan untuk mendapatkan data keterlaksanaan pembelajaran dengan model RML. Observasi yang dilakukan oleh pengamat sebanyak 2 (dua) orang sejawat dari guru MAN 3 Lombok Tengah. Pengamat mengisi lembar observasi keterlaksanaan pembelajaran dengan memberikan tanda $(\sqrt{ })$ pada bagian penskoran yang sesuai dari setiap aspek kegiatan yang teramati. Hasil pengisian lembar observasi keterlaksanaan pembelajaran yang diperoleh berupa skor dengan rentang $1-4$, dengan kategori $1=$ tidak baik, 2 = kurang baik, 3 = baik, dan 4 = sangat baik. Skor tiap aspek yang didapat dari semua pertemuan yang telah dilaksanakan pada setiap siklus, dihitung skor rata-rata, kemudian diinterpretasikan dalam bentuk interval rata-rata skor dan kriteria seperti pada Tabel 7 sebagai berikut.

Tabel 7. Interval Skor Rata-rata dan Kriteria Keterlaksanaan Pembelajaran (diadaptasi dari Ratumanan \& Laurens, 2006)

\begin{tabular}{cc}
\hline Interval skor rata-rata & Kriteria skor rata-rata \\
\hline $1,00-1,8$ & Kurang baik $(\mathrm{K})$ \\
$1,9-2,7$ & Cukup baik $(\mathrm{C})$ \\
$2,8-3,6$ & Baik (B) \\
$>3,6$ & Sangat baik (SB) \\
\hline
\end{tabular}

Keterlaksanaan pembelajaran dikatakan berhasil (reliabel) jika rata-rata skor yang diberikan pengamat terhadap keterlaksanaan pembelajaran mencapai $75 \%$ dengan kategori baik dan/atau sangat baik (Borich, 1994).

\section{Teknik tes}

Teknik tes digunakan untuk mendapatkan data kemampuan berpikir kritis. Tes diberikan kepada siswa setelah menyelesaikan pembelajaran setiap siklus, selanjutnya hasil tes dievaluasi untuk mendapatkan nilai yang menyatakan kemampuan berpikir kritis siswa pada setiap siklus. Data kemampuan berpikir kritis pada setiap siklus dianalisis dengan menggunakan rumus berikut ini.

$$
K B K=\frac{\text { skor yang diperoleh siswa }}{\text { skor maksimal }} \times 100
$$

Keterangan: $K B K=$ kemampuan berpikir kritis. bawah ini.

Skor yang diperoleh dikategorisasi ke dalam 4 (empat) kriteria seperti pada Tabel 8 di Tabel 8. Kriteria Kemampuan Berpikir Kritis Siswa

\begin{tabular}{cc}
\hline Kriteria & Nilai \\
\hline Sangat Baik (SB) & $80 \leq \mathrm{KBK} \leq 100$ \\
Baik (B) & $70 \leq \mathrm{KBK} \leq 79$ \\
Cukup (C) & $60 \leq \mathrm{KBK} \leq 69$ \\
Kurang (K) & KBK $<60$ \\
\hline
\end{tabular}

Kemampuan berpikir kritis siswa dikatakan berhasil apabila mencapai 85\% siswa mendapatkan nilai dengan kategori baik dan sangat baik, karena syarat siswa dikatakan tuntas jika hasil yang dicapai di atas nilai KKM mata pelajaran fisika MAN 3 Lombok Tengah sebesar 70 .

3. Teknik penilaian kinerja

Teknik ini digunakan untuk mendapatkan data keterampilan metakognisi siswa melalui penilaian kinerja siswa yang tercermin dari hasil pengisian LKS, dengan memberikan tanda $(\sqrt{ })$ pada bagian penskoran dari setiap indikator yang dinilai. Data keterampilan metakognisi siswa selama pembelajaran pada setiap siklus dianalisis dengan rumus sebagai beikut. 


$$
K M=\frac{\text { skor yang diperoleh siswa }}{\text { skor maksimal seluruhitem }} x \text { skor maksimal }
$$

Keterangan: $K M=$ keterampilan metakognisi siswa siswa

Skor yang diperoleh siswa selanjutnya dikonversi menjadi 4 (empat) kategori, didasarkan pada Permendikbud No. 81 A Tahun 2013 tentang implementasi kurikulum yang diadaptasi oleh Muhali (2018) seperti pada Tabel 9 di bawah ini.

Tabel 9. Interval dan Kriteria Skor Rata-rata Ketermpilan Metakognisi Siswa

Interval skor rata-rata

$A \leq 1,33$
$1,33<A \leq 2,33$
$2,33<A \leq 3,33$
$3,33<A \leq 4,00$

Kriteria skor rata-rata

Kurang baik $(\mathrm{K})$

Cukup baik (C)

Baik (B)

Sangat baik (SB)

\section{Teknik angket}

Teknik ini digunakan untuk mendapatkan data kesadaran metakognisi siswa, yang diperoleh dengan memberikan angket untuk diisi oleh siswa setelah selesai pembelajaran pada setiap siklus. Angket yang diisi peserta didik dilakukan menurut kondisi yang dirasakan dan dialaminya pada saat pembelajaran dengan model RML dilaksanakan. Hasil pengisian angket selanjutnya dianalisis dengan menggunakan persamaan sebagai berikut.

$$
K s M=\frac{\text { skor yang diperoleh siswa }}{\text { skor maksimal ideal }} \times \text { skol maksimal }
$$

Keterangan: $\mathrm{KsM}=$ kesadaran metakognisi

Skor kesadaran metakognisi yang diperoleh siswa selanjutnya dikonversi menjadi 4 (empat) kategori, didasarkan pada Permendikbud No. 81A Tahun 2013 tentang Implementasi Kurikulum seperti pada Tabel 9 yang telah diuraikan sebelumnya.

\section{HASIL PENELITIAN DAN PEMBAHASAN Hasil Penelitian}

Hasil penelitian berupa data-data yang terkumpul selama pelaksanaan kegiatan pembelajaran atau penelitian dengan menggunakan instrumen yang telah ditetapkan untuk mengukur setiap variabel. Data hasil penelitian ini terdiri dari: (1) data keterlaksanaan pembelajaran, (2) data kemampuan berpikir kritis, (3) data keterampilan metakognisi, dan (4) data kesadaran metakognisi siswa yang dibelajarkan menggunakan model RML. Data dan deskripsi data selengkapnya dijelaskan sebagai berikut.

\section{Data keterlaksanaan pembelajaran dengan model RML}

Data keterlaksanaan pembelajaran diperoleh dari hasil pengamatan yang dilakukan oleh observer terhadap kegiatan-kegiatan pembelajaran yang dilaksanakan oleh guru setiap pertemuan pada masing-masing siklus dengan menggunakan model RML. Data rata-rata keterlaksanaan pembelajaran setiap pertemuan pada masing-masing siklus seperti tercantum pada Tabel 10 di bawah ini.

\begin{tabular}{|c|c|c|c|c|c|c|c|c|}
\hline \multirow{2}{*}{ Tahap/Kegiatan Pembelajaran } & \multicolumn{2}{|c|}{ Penilaian Siklus I } & \multicolumn{3}{|c|}{ Penilaian Siklus II } & \multicolumn{3}{|c|}{ Penilaian Siklus III } \\
\hline & $\bar{X}_{P 1} \bar{X}_{P 2}$ & $\bar{X}_{S 1}$ & $\bar{X}_{P 1}$ & $\bar{X}_{P 2}$ & $\bar{X}_{S 2}$ & $\bar{X}_{P 1}$ & $\bar{X}_{P 2}$ & $\bar{X}_{S 3}$ \\
\hline efleksi orien & & & & & & & & \\
\hline Pen & $3,003,00$ & 3,00 & 3,00 & 3,50 & 3,25 & 4,00 & 4,00 & 4,00 \\
\hline formasi dan kondi & $2,502,50$ & 2,50 & 3,00 & 3,00 & 3,00 & 3,00 & 3,50 & 3,25 \\
\hline Menilai kefamiliaran dengan tugas & $2,00 \quad 2,50$ & 2,50 & 3,00 & 2,50 & 2,75 & 3,00 & 3,00 & 3,00 \\
\hline $\begin{array}{l}\text { Menilai tingkat kesulitan dan } \\
\text { peluang untuk berhasil }\end{array}$ & 2,00 & 2,00 & 2,50 & 2,50 & 2,50 & 3,00 & 3,00 & 3,00 \\
\hline $\begin{array}{l}\text { Refleksi melalui penyampaian } \\
\text { fenomena konflik kognitif } \\
\text { Fase 2, Refleksi organisasi }\end{array}$ & $2,002,00$ & 2,00 & 2,50 & 3,00 & 2,75 & 3,50 & 3,00 & 3,25 \\
\hline
\end{tabular}

Tabel 10. Data Keterlaksanaan Pembelajaran Model RML 


\begin{tabular}{|c|c|c|c|c|c|c|c|c|}
\hline \multirow{2}{*}{ Tahap/Kegiatan Pembelajaran } & \multicolumn{2}{|c|}{ Penilaian Siklus I } & \multicolumn{3}{|c|}{ Penilaian Siklus II } & \multicolumn{3}{|c|}{ Penilaian Siklus III } \\
\hline & $\bar{X}_{P 1} \bar{X}_{P 2}$ & $\bar{X}_{S 1}$ & $\bar{X}_{P 1}$ & $\bar{X}_{P 2}$ & $\bar{X}_{S 2}$ & $\bar{X}_{P 1}$ & $\bar{X}_{P 2}$ & $\bar{X}_{S 3}$ \\
\hline $\begin{array}{l}\text { Identifikasi sub tujuan dan tujuan } \\
\text { akhir }\end{array}$ & $2,502,00$ & 2,50 & 2,50 & 3,00 & 2,75 & 3,00 & 3,00 & 3,00 \\
\hline $\begin{array}{l}\text { Membuat rencana global } \\
\text { Organisasi data }\end{array}$ & $\begin{array}{ll}2,00 & 2,00 \\
2,00 & 2,50\end{array}$ & $\begin{array}{l}2,00 \\
2,25\end{array}$ & $\begin{array}{l}2,50 \\
2,00\end{array}$ & $\begin{array}{l}2,50 \\
2,00\end{array}$ & $\begin{array}{l}2,50 \\
2,00\end{array}$ & $\begin{array}{l}3,50 \\
3,00\end{array}$ & $\begin{array}{l}3,00 \\
4,00\end{array}$ & $\begin{array}{l}3,25 \\
3,50\end{array}$ \\
\hline $\begin{array}{l}\text { Refleksi melalui penyajian } \\
\text { fenomena anomali } \\
\text { Fase 3, Refleksi eksekusi }\end{array}$ & $2,503,00$ & 2,75 & 2,50 & 2,50 & 2,50 & 3,00 & 3,00 & 3,00 \\
\hline Melaksanakan perencanaan lokal & $2,002,00$ & 2,00 & 3,00 & 3,00 & 3,00 & 3,00 & 4,00 & 3,50 \\
\hline $\begin{array}{l}\text { Memonitor kemajuan pelaksanaan } \\
\text { perencanaan lokal dan global }\end{array}$ & $2,002,00$ & 2,00 & 2,00 & 2,00 & 2,00 & 3,50 & 3,00 & 3,25 \\
\hline $\begin{array}{l}\text { Membuat/merumuskan keputusan } \\
\text { Refleksi melalui proses internalisasi } \\
\text { Fase 4, Refleksi verifikasi }\end{array}$ & $\begin{array}{ll}2,00 & 2,00 \\
3,00 & 2,50\end{array}$ & $\begin{array}{l}2,00 \\
2,50\end{array}$ & $\begin{array}{l}3,00 \\
3,00\end{array}$ & $\begin{array}{l}3,00 \\
3,00\end{array}$ & $\begin{array}{l}3,00 \\
3,00\end{array}$ & $\begin{array}{l}3,50 \\
3,50\end{array}$ & $\begin{array}{l}4,00 \\
3,50\end{array}$ & $\begin{array}{l}3,75 \\
3,50\end{array}$ \\
\hline Justifikasi keputusan akhir & $2,00 \quad 2,00$ & 2,00 & 2,50 & 3,00 & 2,75 & 3,00 & 4,00 & 3,50 \\
\hline $\begin{array}{l}\text { Refleksi melalui penyajian } \\
\text { fenomena baru }\end{array}$ & $2,002,00$ & 2,00 & 3,00 & 3,00 & 3,00 & 4,00 & 4,00 & 4,00 \\
\hline $\begin{array}{l}\text { Pengelolaan waktu } \\
\text { Pengelolaan kelas }\end{array}$ & $2,002,00$ & 2,00 & 3,00 & 3,00 & 3,00 & 4,00 & 4,00 & 4,00 \\
\hline Antus & 3,003, & & 3,50 & 3,50 & 3,50 & 4,00 & 4,00 & 4,00 \\
\hline Antusiasme guru & $3,00 \quad 3,00$ &, 00 & 3,50 & 4,00 & 3,75 & 4,00 & 4,00 & 4,00 \\
\hline
\end{tabular}

Keterangan: $\overline{\boldsymbol{X}}_{\boldsymbol{P 1}}=$ rata-rata pertemuan 1, $\overline{\boldsymbol{X}}_{\boldsymbol{P 2}}=$ rata-rata pertemuan $2, \overline{\boldsymbol{X}}_{\boldsymbol{S 1}}=$ rata-rata siklus I, $\overline{\boldsymbol{X}}_{\boldsymbol{S} \mathbf{2}}=$ rata-rata siklus II, dan $\overline{\boldsymbol{X}}_{\boldsymbol{S} \mathbf{3}}=$ rata-rata siklus III

Berdasarkan data pada Tabel 10 tersebut kriteria keterlaksanaan pembelajaran sesuai dengan interval skor rata-rata pada setiap siklus pembelajaran menggunakan model RML disajikan pada Tabel 11 sebagai berikut.

Tabel 11. Persentase Berdasarkan interval dan Kriteria Keterlaksanaan Pembelajaran Setiap Siklus

\begin{tabular}{ccccc}
\hline $\begin{array}{c}\text { Kriteria skor rata- } \\
\text { rata }\end{array}$ & Interval skor rata-rata & Siklus I (\%) & Siklus II (\%) & Siklus III (\%) \\
\hline Kurang baik (K) & $1,00-1,8$ & 0,00 & 0,00 & 0,00 \\
Cukup baik (C) & $1,9-2,7$ & 83,33 & 50,00 & 0,00 \\
Baik (B) & $2,8-3,6$ & 16,67 & 44,44 & 66,67 \\
Sangat baik (SB) & $>3,6$ & 0,00 & 5,56 & 33,33 \\
\hline
\end{tabular}

Berdasarkan data pada Tabel 10 dan Tabel 11 di atas, keterlaksanaan pembelajaran pada siklus I dan II dinyatakan tidak reliabel disebabkan karena persentase keterlaksanaan pembelajaran dengan kategori baik dan sangat baik 16,67 (siklus I) dan 50\% (siklus II) keduanya masih di bawah 75\%. Hal ini sesuai dengan pendapat Borich (1994) bahwa keterlaksanaan pembelajaran dikatakan reliabel apabila mencapai persentase keterlaksanaan minimal sebesar $75 \%$ berkategori baik dan/atau sangat baik. Keterlaksanaan pembelajaran pada siklus III mencapai persentase sebesar $66,67 \%$ dan $33,33 \%$ dengan kategori baik dan sangat baik, oleh karena itu sesuai dengan kriteria reliabilitas menurut Borich (1994) maka keterlaksanaan pembelajaran pada siklus III dinyatakan reliabel.

\section{Data kemampuan berpikir kritis siswa dengan model RML}

Data kemampuan berpikir kritis diperoleh dari hasil tes siswa menggunakan 4 (empat) soal uraian pada setiap siklus, yang dilakukan setelah menyelesaikan kegiatan pembelajaran setiap siklus dengan menggunakan model RML. Data kemampuan berpikir kritis siswa pada setiap siklus pembelajaran disajikan pada Tabel 12 di bawah ini.

Tabel 12. Data Kemampuan Berpikir Kritis siswa pada Setiap Siklus Pembelajaran

\begin{tabular}{cccc}
\hline \multirow{2}{*}{$\mathbf{c}$} & \multicolumn{3}{c}{ Rata-rata Kemampuan Berpikir Kritis } \\
\cline { 2 - 4 } & Siklus I & Siklus II & Siklus III \\
\hline 20 & 62,38 & 70,50 & 76,75 \\
\hline
\end{tabular}


Data pada Tabel 12 di atas menunjukkan bahwa pada siklus I kemampuan berpikir kritis siswa yang dibelajarkan dengan model RML mencapai kategori cukup baik dilihat dari ratarata skor kemampuan berpikir kritis pada 20 siswa sebesar 62,38 dan telah mengalami peningkatan dengan kategori baik pada siklus II dan III. Data kemampuan berpikir kritis siswa pada siklus II dan III telah mencapai peningkatan dengan perolehan skor rata-rata sebesar 70,50 (siklus I) dan 76,75 (siklus II) tetapi kedua skor tersebut masih pada kategori baik (Ratumanan \& Laurens, 2006) .

Berdasarkan data pada Tabel 12, persentase jemlah siswa pada setiap siklus pembelajaran sesuai kategori dan interval kemampuan berpikir kritis menurut Ratumanan \& Laurens (2006) disajikan seperti pada Tabel 13 sebagai berikut.

Tabel 13. Persentase Jumlah Siswa Berdasarkan Interval dan Kriteria Kemampuan Berpikir Kritis Setiap Siklus

\begin{tabular}{ccccc}
\hline Kriteria & Nilai & Siklus I (\%) & Siklus II (\%) & Siklus III (\%) \\
\hline Sangat Baik (SB) & $80 \leq \mathrm{KBK} \leq 100$ & - & 10,00 & 45,00 \\
Baik (B) & $70 \leq \mathrm{KBK} \leq 79$ & 45,00 & 75,00 & 40,00 \\
Cukup (C) & $60 \leq \mathrm{KBK} \leq 69$ & 20,00 & 15,00 & 10,00 \\
Kurang (K) & KBK $<60$ & 35,00 & - & 5,00 \\
\hline
\end{tabular}

Data pada Tabel 13 menunjukkan bahwa pembelajaran dengan model RML pada siklus I belum mencapai ketuntasan klasikal karena persentase siswa yang mendapatkan nilai minimal 70 (sesuai KKM mata pelajaran fisika MAN 3 Lombok Tengah) sebesar $45 \%$. Persentase siswa yang mencapai atau melebihi KKM pada siklus II sebanyak $75 \%$ dengan kategori baik, dan 10\% dengan kategori sangat baik, sehingga hasil pada siklus II tuntas secara klasikal (85\% siswa mencapai/melebihi KKM). Hasil ini mengindikasikan bahwa kegiatan penelitian dapat dihentikan sesuai dengan bagan alur penelitian pada Gambar 1 menurut Kemmis \& Mc. Taggart (Sukaisih et al., 2020). Pembelajaran siklus III dilakukan oleh peneliti dengan maksud untuk melihat konsistensi perolehan kemampuan berpikir kritis siswa yang dibelajarkan dengan model RML. Hasil yang diperoleh sebesar $40 \%$ dengan kategori baik dan $45 \%$ dengan kategori sangat baik dan dari perolehan jumlah persentase kedua kategori tersebut dinyatakan pembelajaran tuntas secara klasikal (85\% siswa telah mencapai/melebihi KKM), hasil ini menunjukkan bahwa model RML secara konsisten dapat membelajarkan kemampuan berpikir kritis siswa.

Berdasarkan data sesuai Tabel 12 di atas dapat diidentifikasi pencapaian skor kemampuan berpikir kritis siswa pada setiap indikator, hasil identifikasi disajikan pada Tabel 14 berikut ini.

Tabel 14, Skor Kemampuan Berpikir Kritis pada Setiap Indikator

\begin{tabular}{lcccccc}
\hline \multicolumn{1}{c}{ Indikator } & Siklus I & Kategori & Siklus II & Kategori & Siklus III & Kategori \\
Mengidentifikasi & 74,00 & $\mathrm{~B}$ & 80,50 & $\mathrm{SB}$ & 84,50 & $\mathrm{SB}$ \\
Menghubungkan & 66,50 & $\mathrm{C}$ & 75,50 & $\mathrm{~B}$ & 83,00 & $\mathrm{SB}$ \\
Menganalisis & 63,00 & $\mathrm{C}$ & 71,00 & $\mathrm{~B}$ & 77,00 & $\mathrm{~B}$ \\
Mengevaluasi & 46,00 & $\mathrm{~K}$ & 55,00 & $\mathrm{~K}$ & 62,50 & $\mathrm{C}$ \\
\hline
\end{tabular}

Keterangan: $\mathrm{SB}=$ sangat baik, $\mathrm{B}=$ baik, $\mathrm{C}=$ cukup, $\mathrm{K}=$ kurang,

Data pada Tabel 14 tersebut menunjukkan bahwa kemampuan mengidentifikasi mencapai kategori baik pada siklus I dan mengalami peningkatan menjadi sangat baik pada siklus II dan III. Kemampuan menghubungkan dan menganalisis pada sisklus I mencapai kategori cukup baikdan mengalami peningkatan pada siklus II dengan kategori baik, sedangkan pada siklus III hanya kemampuan menghubungkan yang mengalami peningkatan dengan kategori sangat baik. Kemampuan mengevaluasi pada siklus I dan II mencapai kategori kurang baik walaupun skor yang diperoleh terdapat peningkatan dari 46,00 menjadi 55,00 . Peningkatan pada indikator kemampuan mengevaluasi terjadi pada silkus III dengan skor 62,50 dengan kategori cukup baik.

\section{Data keterampilan metakognisi siswa}

Data keterampilan metakognisi diperoleh dari hasil penilaian kinerja siswa selama melaksanakan kegiatan pembelajaran (praktikum) pada setiap siklus dengan menggunakan model RML. Data keterampilan dapat disajikan dalam Tabel 15 sebagai berikut. 
Tabel 15. Data Keterampilan Metakognisi Siswa pada Setiap Siklus Pembelajaran

\begin{tabular}{cccc}
\hline \multirow{2}{*}{$\mathbf{n}$} & \multicolumn{3}{c}{ Skor rata-rata Keterampilan Metakognisi } \\
\cline { 2 - 4 } & Siklus I & Siklus II & Siklus III \\
\hline 20 & 2,33 & 2,72 & 3,00 \\
\hline
\end{tabular}

Data pada Tabel 15 di atas menunjukkan bahwa keterampilan metakognisi siswa mengalami peningkatan dari 2,33 dengan kategori cukup baik pada siklus I menjadi 2,72 dan 3,00 dengan kategori baik pada siklus II dan III, sesuai dengan kriteria menurut Permendikbud nomor 81A tahun 2013 tentang implementasi kurikulum (dalam Muhali, 2018).

Persentase siswa dengan perolehan skor sesuai interval dan kategori menurut Permendikbud nomor 81A tahun 2013 disajikan seperti dalam Tabel 16 berikut ini.

Tabel 16. Persentase Berdasarkan Interval dan Kriteria Keterampilan Metakognisi Siswa Setiap Siklus

\begin{tabular}{ccccc}
\hline $\begin{array}{c}\text { Kriteria skor rata- } \\
\text { rata }\end{array}$ & $\begin{array}{c}\text { Interval skor rata- } \\
\text { rata }\end{array}$ & $\begin{array}{c}\text { Siklus I } \\
(\%)\end{array}$ & $\begin{array}{c}\text { Siklus II } \\
(\%)\end{array}$ & $\begin{array}{c}\text { Siklus III } \\
(\%)\end{array}$ \\
\hline Kurang baik $(\mathrm{K})$ & $A \leq 1,33$ & 0,00 & 0,00 & 00,00 \\
Cukup baik $(\mathrm{C})$ & $1,33<A \leq 2,33$ & 50,00 & 0,00 & 00,00 \\
Baik (B) & $2,33<A \leq 3,33$ & 50,00 & 100,00 & 75,00 \\
Sangat baik (SB) & $3,33<A \leq 4,00$ & 0,00 & 00,00 & 25,00 \\
\hline
\end{tabular}

Data tersebut menunjukkan sebanyak $50 \%$ siswa mencapai keterampilan metakognisi dengan kategori cukup baik dan baik pada siklus I, sedangkan pada siklus II sebesar $100 \%$ siswa mencapai keterampilan metakognisi siswa dengan kategori baik, dan pada siklus III sebesar $75 \%$ siswa memiliki keterampilan metakognisi dengan kategori baik dan $25 \%$ dengan kategori sangat baik. Hasil ini secara empiris membuktikan bahwa model RML dapat meningkatkan keterampilan metakognisi siswa. Pernyataan ini sesuai dengan hasil penelitian yang dilakukan Muhali (2018) dan Muhali et al. (2019) bahwa model RML secara konsisten dapat meningkatkan keterampilan metakognisi siswa.

Pencapaian skor keterampilan metakognisi siswa pada setiap indicator selama pembelajaran pada setiap siklus dengan model RML dapat disajikan pada Tabel 17 di bawah ini.

Tabel 17. Pencapaian Siswa pada Setiap Indikator Keterampilan Metakognisi pada Setiap Siklus

\begin{tabular}{|c|c|c|c|c|c|c|}
\hline Indikator & Siklus I & Kategori & Siklus II & Kategori & Siklus III & Kategori \\
\hline $\begin{array}{l}\text { Merumusan tujuan umum } \\
\text { pembelajaran dan khusus }\end{array}$ & 2,70 & B & 3,20 & B & 3,40 & SB \\
\hline $\begin{array}{l}\text { Merumuskan masalah dan } \\
\text { hipotesis }\end{array}$ & 2,20 & C & 2,50 & B & 2,90 & B \\
\hline $\begin{array}{l}\text { Membuat rencana pemecahan } \\
\text { masalah }\end{array}$ & 2,70 & B & 3,20 & B & 3,30 & B \\
\hline $\begin{array}{l}\text { Melaksanakan perencanaan } \\
\text { secara sistematis } \\
\text { Mengamati proses }\end{array}$ & 2,40 & B & 2,90 & B & 3,20 & B \\
\hline $\begin{array}{l}\text { pelaksanaan perencanaan } \\
\text { secara kelompok dan individu }\end{array}$ & 2,30 & C & 2,40 & $B$ & 2,60 & $B$ \\
\hline $\begin{array}{l}\text { Memeriksa proses } \\
\text { pelaksanaan perencanaan } \\
\text { secara kelompok dan individu }\end{array}$ & 1,90 & C & 2,30 & C & 2,40 & B \\
\hline $\begin{array}{l}\text { Mencatat atau mengumpulkan } \\
\text { data }\end{array}$ & 2,30 & C & 3,00 & B & 3,30 & B \\
\hline Mengevaluasi hasil & 2,20 & C & 2,40 & $\mathrm{~B}$ & 2,90 & $\mathrm{~B}$ \\
\hline
\end{tabular}

Keterangan: $\mathrm{SB}=$ sangat baik, $\mathrm{B}=$ baik, $\mathrm{C}=$ cukup, $\mathrm{K}=$ kurang,

Data pada Tabel 17 tersebut menunjukkan bahwa pada siklus I siswa dapat merumuskan tujuan umum dan tujuan khusus, membuat rencana pemecahan masalah, dan melaksanakan rencana secara sistematis dalam pembelajaran dengan model RML, dengan 
perolehan skor tertinggi pada indikator merumuskan tujuan umum dan khusus, dan membuat rencana pemecahan masalah, sedangkan skor yang lebih rendah dicapai oleh siswa pada indikator melaksanakan perencanaan secara sistematis. Indikator merumuskan masalah, mengamati proses pelaksanaan perencanaan, mencatat atau mengumpulkan data, dan mengevaluasi hasil dalam kategori cukup baik. Hasil pada soiklus II secara umum terdapat peningkatan skor keterampilan metakognisi pada semua indikator, tetapi indikator kemampuan siswa dalam memeriksa proses pelaksanaan perencanaan secara kelompok dan individu masiih dalam kategori cukup baik. Hal yang sama terjadi pada siklus III terjadi peningkatan skor pada semua indikator, dan indikator memerika pelaksanaan rencana secara individu dan kelompok telah mencapai kategori baik. Dengan demikian, dari hasil ini dapat dinyatakan bahwa model RML dapat meningkatkan keterampilan metakognisi siswa.

\section{Data kesadaran metakognisi siswa}

Data kesadaran metakognisi siswa diperoleh menggunakan angket yang terdiri dari 52 butir pertanyaan yang diberikan kepada siswa pada setiap akhir siklus pembelajaran, hasil selengkapnya tercantum pada Tabel 18 berikut ini.

Tabel 18. Data Skor Rata-rata Kesadaran Metakognisi Siswa pada Setiap Siklus Pembelajaran

\begin{tabular}{cccc}
\hline \multirow{2}{*}{$\mathbf{n}$} & \multicolumn{3}{c}{ Skor rata-rata Kesadaran Metakognisi } \\
\cline { 2 - 4 } & Siklus I & Siklus II & Siklus III \\
\hline 20 & 2,02 & 3,04 & 3,08 \\
\hline
\end{tabular}

Data pada Tabel 18 menunjukkan bahwa skor rata-rata kesadaran metakognisi pada setiap siklus pembelajaran mengalami peningkatan yaitu dari 2,02 dengan kategori cukup pada siklus I menjadi 3,04 pada siklus II dan 3,08 pada siklus III dengan kategori baik.

Persentase siswa dalam pencapaian skor dengan kriteris dan kategori menurut Permendikbud nomor 18A (dalam Muhali, 2018) disajikan pada Tabel 19 di bawah ini.

Tabel 19. Persentase Berdasarkan Interval dan Kriteria Kesadaran Metakognisi Siswa Setiap Siklus

\begin{tabular}{ccccc}
\hline Kriteria skor rata-rata & Interval skor rata-rata & Siklus I (\%) & Siklus II (\%) & Siklus III (\%) \\
\hline Kurang baik (K) & $A \leq 1,33$ & 0,00 & 0,00 & 0,00 \\
Cukup baik (C) & $1,33<A \leq 2,33$ & 100,00 & 0,00 & 0,00 \\
Baik (B) & $2,33<A \leq 3,33$ & 0,00 & 100,00 & 100,00 \\
Sangat baik (SB) & $3,33<A \leq 4,00$ & 0,00 & 0,00 & 0,00 \\
\hline
\end{tabular}

Data pada Tabel 19 menunjukkan bahwa kesadaran metakognisi siswa pada siklus I sebanyak 100\% siswa mencapai kategori cukup baik, pada siklus II dan III mengalami peningkatan pada semua siswa dengan kategori baik. Peningkatan skor yang sangat kecil terjadi dari siklus II ke siklus III sehingga dapat dikatakan tidak menimbulkan perubahan yang berarti.

Kesadaran metakognisi pada setiap indikator sesuai hasil pengisian angket oleh mahasiswa pada setiap siklus dapat disajikan pada Tabel 20 sebagai berikut.

Tabel 20. Kesadaran Metakognisi pada Setiap Indikator

\begin{tabular}{ccccccc}
\hline Indikator & Siklus I & Kategori & Siklus II & Kategori & Siklus III & Kategori \\
\hline DK & 2,03 & C & 3,07 & B & 3,08 & B \\
PK & 1,99 & C & 3,09 & B & 3,10 & B \\
CK & 1,98 & C & 2,99 & B & 3,03 & B \\
P & 2,06 & C & 3,16 & B & 3,19 & B \\
IMS & 2,09 & C & 3,06 & B & 3,09 & B \\
M & 2,04 & C & 3,00 & B & 3,06 & B \\
D & 2,00 & C & 3,01 & B & 3,08 & B \\
E & 1,98 & C & 2,98 & B & 3,03 & B \\
\hline
\end{tabular}

Keterangan:

$\mathrm{DK}=$ declarative knowledge, $\mathrm{PK}=$ procedural knowledge, $\mathrm{CK}=$ conditional knowledge, $\mathrm{P}=$ planning, $\mathrm{IMS}=$ information management strategy, $\mathrm{M}=$ monitoring, $\mathrm{D}$ = debugging, $\mathrm{E}=$ evaluation, $\mathrm{C}=$ cukup, dan $\mathrm{B}=$ baik. 
Data pada Tabel 20 di atas, pada siklus I pencapaian siswa pada semua indikator kesadaran metakognisi dengan kategori cukup baik, sedangkan pada siklus II dan III terjadi peeningkatan pada semua indikator dengan kategori baik. Peningkatan skor yang sangat kecil terjadi dari siklus II ke siklus III tanpa terjadi perubahan kategorir pencapaian pada siklus akhir. Namun demikian, secara umum dapat dikatakan bahwa model RML dapat meeningkatkan kesadaran metakognisi siswa dalam pembelajaran fisika.

\section{Pembahasan}

Aspek penting yang dikaji pada bagian ini adalah keterlaksanaan pembelajaran, peningkatan kemampuan berpikir kritis, peningkatan keterampilan metakognisi, dan peningkatan kesadaran metakognisi. Keempat aspek tersebut diuraikan sebagai berikut.

\section{Keterlaksanaan pembelajaran}

Keterlaksanaan pembelajaran dengan model RML pada setiap siklus mengalami peningkatan dilihat dari persentase keterlaksanaan dari 83,33\% kategori cukup dan 16,67\% dengan kategori baik pada siklus I menjadi 50\% kategori cukup dan 44,44\% kategori baik, dan $5,56 \%$ sangat baik pada siklus II, dan meningkat menjadi $66,67 \%$ kategori baik, dan $33,33 \%$ sangat baik pada siklus III. Data ini mengindikasikan bahwa model RML dapat diimplementasikan dengan baik pada pembelajaran fisika.

Pembelajaran pada siklus I, kebanyakan kegiatan pada setiap fase model RML dilaksankaan dengan cukup baik karena kegiatan yang disajikan sangat berbeda dengan yang telah biasa dilakukan guru fisika dalam pembelajaran. Seperti pada fase satu (refleksi orientasi), hanya kegiatan penyampaian tujuan yang dapat terlaksana dengan baik, tetapi kegiatan seperti analisis informasi dan kondisi, menilai kefamiliaran dengan tugas yang disajikan, menilai tingkatkat kesulitan dan peluang untuk berhasil, dan penyampaian fenomena konflik kognitif sebagai kegiatan akhir fase ini untuk merefleksi semua kegiatan fase satu dilaksanakan dengan cukup baik. Hal ini terjadi karena ketika guru menyajikan kegiatan fase satu, siswa mengalami kesulitan dalam melakukan kegiatan-kegiatan tersebut, banyak bertanya tentang pembelajaran yang berbeda dari sebelumnya, bukan bertanya tentang konsep yang dipelajari. Ketika guru menyampaikan fenomena konflik kognitif, siswa hanya terpaku pada fenomena yang disajikan tanpa melakukan refleksi secara sadar pada konsep pengetahuan atau kegiatan yang telah dilakukan, sehingga guru kembali mengarahkan siswa untuk melihat konsep atau proses sebelumnya. Kegiatan pada fase dua (refleksi organisasi), tiga (fase refleksi eksekusi) dan fase empat (refleksi verifikasi) juga terlaksana dengan kategori cukup baik namun refleksi melalui penyajian fenomena anomali (fase dua), proses internalisasi (fase tiga) telah lebih baik dari pada refleksi fase satu karena sudah mulai terbiasa dalam melakukan kegiatan tersebut. Fenomena pembelajaran pada siklus I terjadi karena guru mengalami kesulitan dalam menanamkan refleksi pada setiap fase. Keadaan seperti ini menyebabkan guru tidak dapat melakukan pengelolaan kelas dan waktu dengan baik. Fenomena yang sama terjadi juga sesuai hasil penelitian sebelumnya (Sukaisih \& Muhali, 2013) siswa kesulihat melihat kembali pekerjaan selama menyelesaikan masalah. Sukaisih et al. (2020) telah menerapkan strategi konflik kognitif dan mendapatkan bahwa: (1) guru belum terbiasa menyajikan fenomena konflik kognitif dalam pembelajaran, sehingga berdampak pada pengelolaan kelas dan penggunaan waktu selama pembelajaran, (2) siswa mengalami kesulitan dalam menghubungkan fenomena konflik kognitif yang disajikan guru dengan pengetahuan yang telah dimiliki sebelumnya karena belum terbiasa dengan pembelajaran yang diterapkan oleh guru, yang menyebabkan siswa mengalami kesulitan dalam memonitor dan meregulasi pengetahuannya (Tosun \& Senocak, 2013). Menurut Cowan (1998) menyatakan bahwa siswa akan merefleksi pengetahuannya jika menyadari adanya perbedaan antara pengetahuan yang dimiliki dengan pengetahuan baru, misalnya melaui penyajian fenomena kontekstual. Siswa juga akan merefleksi proses berpikirnya apabila mengidentifikasi adanya permasalahan yang harus diselesaikan (Ong, 2010).

Pembelajaran pada siklus II telah mengalami peningkatan persentase keterlaksanaan kegiatan berkategori baik yaitu pada kegiatan penyampaian tujuan, dan analisis informasi dan kondisi (fase satu), melaksanan perencanaan, merumuskan keputusan dan refleksi melalui proses internalisasi (fase tiga), dan refleksi dendan penyajian fenomena baru (fase empat). 
Hal ini disebabkan karena guru telah mampu melalukan melakukan pengelolaan kelas dan waktu dengan baik dan juga guru sangat antusias dalam menyajikan pembelajaran dengan model RML (hal ini sebagai bentuk refleksi pada siklus I). Perubahan tingkah laku sebagai hasil dari pengalaman menurut (Gage \& Berliner, 1985), pembelajaran merupakan akibat adanya interaksi stimulus dan respon (Slavin, 2000).

Pembelajaran pada siklus III, jauh mengalami peningkatan keterlaksanaan pembelajaran dari siklus I dan II, dilihat dari persentase keterlaksanaan sebesar $100 \%$ terlaksana dengan baik dan sangat baik, walaupun masih ada kegiatan yang perlu diperhatikan dalam pembelajaran karena memiliki skor paling rendah yaitu 3,00 yaitu: (1) menilai kefamiliaran dengan tugas, (2) menilai tingkat kesukaran dan peluang untuk berhasil (kegiatan fase satu), (3) identifikasi sub tujuan dan tujuan akhir, dan (4) refleksi melalui penyajian fenomena anomali (kegiatan fase dua). Hasil dari kegiatan-kegiatan metakognisi dapat berupa hasil yang umum misalnya mengklasifikasi informasi yang relevan dengan masalah yang dihadapi, atau dapat berupa hasil yang spesifik seperti menemukan solusi khusus yang sesuai dengan teori atau konsep yang benar untuk membantu siswa memecahkan masalah yang dihadapi (Veenman, 2012). Penyajian fenomena anomali dalam pembelajaran fisika sangat penting untuk diperhatikan (Prayogi et al., 2019).

Berdasarkan uraian di atas maka model RML yang memiliki 4 (empat) fase yaitu refleksi orientasi, refleksi organisasi, refleksi eksekusi, dan refleksi verifikasi yang menekankan pada kegiatan refleksi pada setiap fase model melalui penyajian fenomena konflik kognitif, penyajian fenomena anomali, proses internalisasi, dan penyajian fenomena baru dapat diimplementasikan dalam pembelajaran fisika.

\section{Peningkatan kemampuan berpikir kritis}

Model RML diimplementasikan untuk meningkatkan kemampuan berpikir kritis siswa. Hasil yang diperoleh bahwa pada siklus I sebesar 45\% siswa dengan skor kemampuan berpikir kritis memcapai/melebihi KKM, sedangkan siklus II dan sebesar $85 \%$ siswa dengan skor kemampuan berpikir kritis mencapai/melebihi KKM, dan mencapai angka persentase ketuntasan secara klasikal. Capaian pada masing-masing indikator berpikir kritis dilihat dari hasil evaluasi setiap siklus, indikator kemampuan mengidentifikasi, menghubungkan, dan menganalisis mencapai kategori sangat baik dan baik, artinya bahwa model RML dapat digunakan untuk membelajarkan kemampuan berpikir kritis siswa dalam pembelajaran fisika. Indikator berpikir kritis yaitu kemampuan mengevaluasi mencapai peningkatan dengan kategori cukup, hal ini menunjukkan bahwa siswa belum mampu menyelesaikan soal-soal pada tingkatan yang lebih tinggi seperti evaluasi. Hal yang sama juga ditemui dalam penelitian Sukaisih et al. (2020) bahwa pencapaian skor pada kemampuan siswa menyelesaikan soal dengan indikator evaluasi berkategori rendah, sedangkan indikator seperti mengidentifikasi, menghubungkan, dan menganalisis dapat dicapai dengan baik oleh siswa. Namun, secara umum keempat indikator kemampuan berpikir kritis mengalami peningkatan skor pada kemampuan berpikir kritis.

Model RML dalam pelaksanaannya menekankan aspek-aspek berpikir kritis siswa dengan melibatkan pengetahuan faktual, konseptual, prosedural, dan kondisional dalam memfasilitasi siswa dalam penyelesaian tugas. Penekanan proses refleksi melalui fenomena konflik kognitif, fenomena anomali, proses internalisasi dan penyajian fenomena baru memungkinkan siswa untuk melihat kembali pengetahuannya, melihat kesesuaian pengetahuan tersebut dalam penggunaannya dalam penyelesaian tugas, sampai pada keyakinan untuk mengambil kesimpulan, dan hal tersebut dilakukan secara sadar. Menurut $\mathrm{Ku}$ et al. (2014) bahwa program yang ditujukan secara spesifik dalam meningkatkan kemampuan berpikir kritis harus mendorong siswa secara sadar menggunakan proses berpikirnya.

Kemampuan berpikir kritis seperti mengidentifikasi, menghubungkan, dan menganalisis dalam pembelajaran dengan model RML telah dilatihkan lebih awal pada fase satu melalui kegiatan analisis informasi dan kondisi sesuai konteks permasalahan/tugas, pada fase dua melalui kegiatan pengorganisasian data, fase tiga melalui memonitor pelaksanaan perencanaan dalam penyelesaian tugas dan mengevaluasi keputusan, dan diperkuat dengan 
adanya bentuk kegiatan yang mengarahkan siswa pada proses refleksi. Kegiatan-kegiatan ini tentunya dapat membangun pengetahuan siswa sehingga mendorong kemampuan berpikir kritis menjadi lebih baik. Sesuai dengan pendapat Yang et al. (2005) bahwa pengembangan kemampuan berpikir kritis tidak dapat dipisahkan dari keaktifan dalam membamgun pengetahuannya sendiri. Berpikir kritis sebagai pemikiran yang masuk akal dan reflektif dalam mengambil keputusan tentang pengetahuan yang harus diyakini dan dilakukan (Ennis, 1996). Dengan demikian dapat dinyatakan bahwa model RML dapat membelajarkan kemampuan berpikir kritis siswa dalam pembelajaran fisika.

\section{Peningkatan keterampilan metakognisi}

Model RML dalam implementasinya dapat meningkatkan keterampilan metakognisi siswa, dilihat dari peningkatan persentase siswa mencapai $100 \%$ dengan kategori baik dan sangat baik pada siklus II dan III. Hasil ini telah mampu memperbaiki hasil pada penelitian sebelumnya (Sukaisih et al., 2020) bahwa peningkatan keterampilan metakognisi hanya sampai pada $80 \%$ siswa yang mencapai skor dengan kategori baik dan sangat baik.

Keterampilan metakognisi siswa tercermin kinerja dalam menggunakan LKS sebagai media belajar. LKS yang digunakan membantu siswa dalam mengkonstruksi pengetahuannya dalam penyelesaian tugas melalui pelaksanaan perencanaan khusus dan perencanaan umum. Menurut Muhali (2018) ketersediaan LKS berbasis model RML dapat memfasilitasi siswa belajar membangun pengetahuan dalam melakukan pengukuran, atau percobaan/pengamatan. LKS model RML memberikan kesempatan kepada siswa untuk melakukan proses ilmiah dalam memahami dan menemukan konsep yang dipelajari, seperti yang termuat dalam indikator keterampilan metakognisi meliputi: (1) Merumuskan tujuan pembelajaran baik secara umum maupun khusus, (2) Merumuskan masalah dan hipotesis penyelesaian masalah yang relevan dengan tujuan pembelajaran yang dirumuskan, (3) Membuat perencanaan pemecahan masalah untuk membuktikan hipotesis yang telah diajukan, (4) Melaksanakan perencanaan secara sistematis, (5) Mengamati proses pelaksanaan perencanaan baik secara individu maupun kelompok, (6) Memeriksa proses pelaksanaan perencanaan baik secara individu maupun kelompok, (7) Membuat catatan atau mengumpulkan data hasil pelaksanaan perencanaan secara detail, (8) Mengevaluasi hasil belajar terkait hubungannya dengan tujuan pada awal kegiatan belajar. LKS model RML juga menyajikan konten atau materi yang sesuai dengan konteks lingkungannya (kontekstual), yang dapat mendukung tercapainya kompetensi dasar. Menurut Lee (2006) bahwa dalam pembelajaran sangat diperlukan pendekatan kontekstual, karena penyajiannya memiliki keutamaan seperti meningkatkan motivasi belajar dan memberikan pemahaman yang lebih baik pada materi yang dibelajarkan.

Dengan demikian, secara umum implementasi model RML yang menekankan pada permasalahan yang menuntut kemampuan siswa dalam memahami dan menemukan konsep melalui percobaan atau pengamatan dapat membelajarkan secara keseluruhan dari indikator keterampilan metakognisi, karena mengalami peningkatan skor pada setiap pertemuan di masing-masing siklus pembelajaran. Sejalan dengan penelitian Kumar et al. (2010) bahwa pembelajaran aktif berbasis permasalahan dalam membelajarkan konsep pada pendidikan sains secara positif berpengaruh terhadap pencapaian akademis dan sikap siswa terhadap pembelajaran sains. Brum \& McKane (1989) menyatakan bahwa belajar sains termasuk fisika tidak dapat terlepas dari kemampuan untuk melakukan observasi, memformulasikan hipotesis yang testable, kemampuan untuk melakukan induksi dan deduksi, merancang dan melaksanakan eksperimen untuk membuktikan hipotesis. Kegiatan-kegiatan tersebut termuat dalam LKS sehingga keterampilan dan aktivitas metakognisi siswa dapat diperbaiki. Nur (2008) menyatakan bahwa dalam kegiatan pembelajaran siswa sebaiknya ditekankan untuk lebih banyak melakukan aktivitas ilmiah seperti merumuskan pertanyaan, berhipotesis, mengamati, menganalisis dan menyimpulkan agar materi yang dipelajari lebih bermakna

\section{Peningkatan kesadaran metakognisi}

Implementasi model RML juga secara umum dapat meningkatkan kesadaran metakognisi siswa, dilihat dari peningkatan yang terjadi pada setiap siklus pembelajaran yang 
mencapai $100 \%$ siswa sadar akan proses berpikirnya, sadar akan pengetahuan dan sadar akan regulasi kognisinya. Hasil ini telah memberikan peningkatan dari penelitian sebelumnya (Sukaisih \& Muhali, 2013) dengan menerapkan pembelajaran pemecahan masalah mencapai persentase $77,14 \%$ siswa memiliki kesadaran metakognisi dengan kategori baik dan sangat baik.

Membelajarkan siswa melalui penyajian fenomena konflik kognitif, fenomena anomali, proses internalisasi, dan fenomena baru melatih siswa untuk terus menerus menggali informasi pengetahuan yang dibutuhkan dalam penyelesaian masalah, memonitor dan mengevaluasi setiap langkah dalam menyelesaikan masalah, sampai pada mengevaluasi keputusan sampai diperoleh keputusan dengan benar. Secara spesifik, kegiatan-kegiatan ini mendorong siswa untuk memahami pengetahuan deklaratif (konseptual dan faktual), yang dapat digunakan untuk membuktikan pengetahuan baru sesuai konteks permasalahan (kondisional) melalui serangkaian langkah atau prosedur dengan strategi-strategi tertentu (prosedural). Dampak dari pembelajaran yang diskenariokan tersebut berbentuk sikap terhadap ilmu atau informasi yang dimiliki yang dapat dipantau. Menurut Flavell (1979) pemantauan dapat melalui tindakan dan interaksi di antara empat kelas fenomena: (1) pengetahuan metakognisi, (2) pengalaman metakognisi, (3) tujuan (atau tugas), dan (4) tindakan (atau strategi). Pengetahuan tentang kognisi (deklaratif, prosedural, dan kondisional) membantu siswa dalam melakukan regulasi kognisi, seperti membuat perencanaan, manajemen informasi, memonitor, memperbaiki strategi dan mengevaluasi. Keterampilan esensial untuk melakukan metakognisi di antaranya: planning (merencanakan), monitoring (memantau), dan evaluating (mengevaluasi) (Woolfolk, 2009).

Dengan demikian, refleksi pada model RML memberikan peran yang sangat penting bagi siswa untuk melatih kesadaran akan pengetahuan tentang kognisinya, dan melatih kesadaran akan regulasi kognisi dalam penyelesaian masalah atau tugas. Bennet et al. (2016) refleksi merupakan bagian esensial dari pengembanagan refleksi evaluatif siswa dalam konteks pembelajaran yang berorientasi pada kegiatan percobaan ilmiah.

\section{KESIMPULAN}

Berdasarkan hasil yang diperoleh maka simpulan dalam penelitian ini adalah model RML dapat diimplementasikan dalam pembelajaran fisika untuk meningkatkan kemampuan berpikir kritis, keterampilan metakognisi, dan kesadaran metakognisi siswa dilihat dari peningkatan persentase keterlaksanaan pembelajaran setiap siklus, pada siklus I sebesar $83,33 \%$ terlaksana dengan cukup baik dan 16,67\% terlaksana dengan baik Keterlaksanaan pembelajaran dengan model RML, siklus II 50\% terlaksana dengan cukup baik, 44,44\% terlaksana dengan baik, dan $5,56 \%$ terlaksana dengan sangat baik, pada siklus III sebesar $66 \%$ terlaksana dengan baik dan 33,33\% terlaksana dengan sangat baik.

Kemampuan berpikir kritis siswa yang dibelajarkan dengan model RML mengalami peningkatan pada setiap siklus pembelajaran, dilihat dari rata-rata kemampuan berpikir kritis siswa pada siklus $\mathrm{I}=62,38$, siklus $\mathrm{II}=70,50$ dan siklus $\mathrm{III}=76,75$ dengan persentase jumlah siswa yang mendapatkan nilai $\geq 70$ sesuai KKM MAN 3 Lombok Tengah sebanyak $45 \%$ pada siklus I, 85\% pada siklus II dan siklus III.

Keterampilan metakognisi siswa yang dibelajarkan dengan model RML mengalami peningkatan pada setiap siklus pembelajaran, yang terlihat dari perolehan rata-rata skor dan persentase siswa yang mendapatkan skor dengan kategori baik dan sangat baik pada siklus $\mathrm{I}=2,33$ dan $50 \%$, siklus $\mathrm{II}=2,72$ dan $100 \%$, dan siklus $\mathrm{III}=3,00$ dan $100 \%$. Kesadaran metakognisi siswa yang dibelajarkan dengan model RML mengalami peningkatan pada setiap siklus pembelajaran, yang terlihat dari perolehan rata-rata skor dan persentase siswa yang mendapatkan skor dengan kategori baik dan sangat baik pada siklus $\mathrm{I}=2,02$ dan $100 \%$ berkategori cukup, siklus II = 3,04 dan $100 \%$, dan siklus III = 3,08 dan $100 \%$.

\section{SARAN}

Berdasarkan temuan yang dihasilkan maka saran pada penelitian ini adalah implementasi model RML dalam pembelajaran sains khususnya fisika dalam melatihkan kemampuan berpikir kritis hendaknya memperhatikan kemampuan siswa dalam 
mengevaluasi pengetahuan dan kesesuaian dalam menggunakan pengetahuan tersebut penyelesaian masalah atau tugas, sehingga penting untuk lebih memfokuskan siswa pada kegiatan memeriksa proses pelaksanaan perencanaan penyelesaian masalah dan penekanan proses refleksi melalui proses internalisasi secara lebih mendalam.

Implementasi model RML dalam membelajarkan keterampilan metakognisi pada pembelajaran fisika, guru hendaknya memperhatikan kemampuan siswa dalam memeriksa proses pelaksanaan perencanaan baik secara individu maupun kelompok sehingga strategi untuk membentuk dan membangun kemandirian dan kelompok penting untuk menjadi pertimbangan. Implementasi model RML pada pembelajaran fisika untuk membelajarkan kesadaran metakognisi menjadi lebih baik lagi maka perlu memilih fenomena/konsep/permasalahan yang lebih dekat dengan lingkungan belajar siswa. Hendaknya guru dalam membelajarkan siswa agar memiliki kemampuan berpikir kritis, memiliki keterampilan dan kesadaran metakognisi yang baik untuk mengimplementasikan model RML karena model ini menekankan pada proses refleksi yamng sangat penting dalam pembelajaran untuk membentuk pebelajar aktif dan mandiri.

\section{UCAPAN TERIMAKASIH}

Penelitian ini tidak menerima hibah khusus dari agensi pendanaan mana pun di sektor publik, komersial, atau nirlaba.

\section{DAFTAR PUSTAKA}

Asy'ari, M., Prayogi, S., Samsuri, T., \& Muhali. (2016). Literatur reviu tentang kaitan berpikir kritis, berpikir kreatif, dan metakognisi dalam pembelajaran. Prosiding Seminar Nasional Pusat Kajian Pendidikan Sains dan Matematika 'assessment of higher order thinking skills', (p, 292-298), 12 Maret 2016. IKIP Mataram, Mataram-Indonesia.

Azizah, R., Yuliati, L. \& Latifah, E. (2015). Kesulitan pemecahan masalah fisika pada siswa SMA. Jurnal Penelitian Fisika dan Aplikasinya, 5(2), 44-50.

Bahtiar, Nur, M., \& Wasis. (2014). Pengaruh model praktikum sains (IPA) fisika berbasis guided inquiry terhadap keterampilan berpikir kritis siswa kelas X MAN 2 Mataram. Prosiding Seminar Nasional Sains dan Inovasi Pembelajaran Berbasis Kearifan Lokal (pp. 408- 416). PKPSM IKIP Mataram, Mataram-Indonesia.

Bennett, D., Power, A., Thomson, C., Mason, B., \& Bartleet, B. L. (2016). Reflection for learning, learning for reflection: Developing Indigenous competencies in higher education. Journal of UniversityTeaching \& Learning Practice, 13(2), 1-19.

Borich, G. D. (1994). Observation skills for effective teaching. New York: Publishing Company. Brum \& McKane. (1989). Study guide biology: Exploring life. New York: John Wiley \& Sons.

Cowan, J. (1998). On become an innovative university teacher. Buckingham: Open University Press.

Ennis, R. H. (1996). Critical thinking. New Jersey: Prentice Hall.

Flavell, J. H. (1976). Metacognitive aspects of problem solving. In L. B. Resnick (Ed.), The nature of intelligence (231-236). Hillsdale, NJ: Erlbaum.

Flavell, J. H. (1979). Metacognition and cognitive monitoring: a new area of cognitivedevelopmentan inquiry. American Psychologist, 34(10), 906- 911.

Gagne, E. D. (1985). The Cognitive Psychology of School Learning. Boston, Toronto: Little, Brown and Company.

Gutulo, S. G. \& Tekello, K. O. (2015). Problems in the teaching and learning of physics at the secondary and prepatory schools, the cases wolaita and dwuro zones. Global Journal of Human-Social Science: G Linguistics \& Education, 15(7), 1-6.

Hapsari, N. D., Widodo, A. (2016). Meningkatkan pengetahuan dan keterampilan metakognisi siswa melalui bahan ajar berbasis konstuktivis-metakognitif. Seminar Nasional Pendidikan dan Saintek, (pp, 591-598). Surakarta: Indonesia.

Ismaimuza, D. (2010). Kemampuan berpikir kritis dan kreatif matematis siswa SMP melalui pembelajaran berbasis masalah dengan strategi konflik kognitif. Disertasi (tidak dipublikasikan). SPs UPI Bandung. 
Kluwe, R. H. (1982). Cobnitive Knowledge and executive control: Metacognition. Springer, 21(1), 201-224.

Ku, K. Y. L., Ho, I. T., Hau, K., \& Lai, E. C M. (2014). Integrating direct and inquirybased instruction in the teaching of critical thinking: An intervention study. Instructional Science, 42(2), 251-269.

Kumar, V. S. Gress, C. L. Z. Hadwin, A. F. Winne, P.H. (2010). Assessing process in CSCL: An ontological approach. Computers in Human Behavior, 26(5), 825-834.

Lai, E. R. (2011). Metacognition: A literature review. Research Report (pp. 1-41). Pearson. Retrieved from: http://www.pearsonassessments.com.

Lee, M. (2006). What does constructivism suggest for science education. Northridge: California State University.

Malhotra, N. K. (2011). Review of marketing research: Spesial issue-marketing legends. Emerald Group Publishing Limited.

McCormick, C. B. (2003). Metacognition and learning. In W. M. Reynolds \& G. E. Miller (Eds.), Handbook of psychology: Educational psychology (pp. 79-102). Hoboken: Wiley.

Muhali. (2018). Pengembangan model pembelajaran reflektif metaakognitif untuk meningkatkan kemampuan metakognisi siswa SMA. Disertasi. Program Pascasarjana, Universitas Negeri Surabaya.

Muhali. (2018b). Arah pengembangan pendidikan masa kini menurut perspektif revolusi industry 4.0. Prosiding Seminar Nasional Lembaga Penelitian dan Pendidikan (LPP) Mandala "Membangun pendidikan yang mandiri dan berkualitas pada era revolusi industry 4.0, (pp. 1-14), 29 September 2009. Universitas Muhammadiyah Mataram, Mataram: Indonesia.

Muhali. (2019). Pembelajaran inovatif abad ke-21. Jurnal Penelitian dan Pengkajian IImu Pendidikan: e-Saintika, 3(2), 25-50.

Muhali, Yuanita, L. \& Ibrahim. M. (2019). The validity and effectiveness of the reflectivemetacognitive learning model to improve students' metacognition ability in Indonesia. Malaysian Journal of Learning and Instruction, 16(2), 33-74.

Nur, M. (2008). Model pembelajaran berdasarkan masalah. Surabaya: Pusat Sains dan Matematika Sekolah Unesa.

Ong, R. (2010). The role of reflection in student learning: A study of its effectiveness in complementing problem based learning environment. Retrieved from: https://www.bradfordvts.co.uk/wpcontent/onlineresources/0307teachinglearning/reflection/ reflection\%20in\%20student\%20learning.

Prayogi, S., Hidayat, S., \& Wulandari, A. (2013). Penerapan model pembelajaran kooperatif dengan strategi pembelajaran POE (predict observe explain) untuk meningkatkan hasil belajar dan kemampuan berpikir kritis siswa di MAN 1 Mataram tahun pelajaran 2012/2013. Jurnal Lensa Kependidikan Fisika, 1(1), 28-36.

Prayogi, S., Muhali, Verawati, N. N. S. P., Asy'ari, M. (2019). Pengembangan model pembelajaran aktif berbasis inkuiri untuk meningkatkan keterampilan berpikir kritis mahasiswa calon guru. Jurnal Pengajaran MIPA, 21(2), 148-153.

Ratumanan \& Laurens. (2011). Evaluasi hasil belajar pada tingkat satuan pendidikan, Edisi 2. Surabaya: Unesa University Press,

Schraw, G. \& Dennison, R. S. (1994). Assessing metacognitive awareness. Contemporary Educational Psychology, 19(1), 460-475.

Slavin, R. E. (2000). Educational Psychology: Theory and Practice. Sixth Edition. Boston: Allyn and Bacon.

Sukaisih, R. \& Muhali. (2013). Meningkatkan kesadaran metakognitif dan hasil belajar siswa melalui penerapan pembelajaran problem solving. Jurnal Pengkajian IImu dan Pembelajaran Matematika dan IPA "Prisma Sains", 2(1), 71-82.

Sukaisih, R., Muhali, \& Asy'ari, M. (2020). Meningkatkan keterampilan berpikir kritis dan metakognisi siswa melalui pembelajaran model pemecahan masalah dengan strategi konflik kognitif, Empiricism Journal, 1(1), 59-80. 
Temel, Senar. 2014. The effect of problem-based learning on pre-service techers' critical thinking dispotitions and perception of problem-solving ability. South African journal of education, 34(1), 1-20.

Tosun, C. \& Senocak, E. (2013). The effects of problem-based learning onmetacognitive awareness and attitudes toward chemistry of prospective teachers with different academic backgrounds. Australian Journal of Teacher Education, 38(3), 61-73.

Veenman, M.V.J. (2012). Metacognition in science education: definitions consituents, and their intricate relation with cognition. In A. Zohar \& Y. J. Dori (Eds.), Metacognition in science education, (pp. 21-36). London: Springer.

Verawati, N. N. S. P., Wahyudi, \& Sahidu, C. (2014). Mengembangkan keterampilan berpikir kritis mahasiswa dengan penerapan model pembelajaran inkuiri. Prosiding Seminar Nasional Sains dan Inovasi Pembelajaran Berbasis Kearifan Lokal (pp. 556-561). PKPSM IKIP Mataram, Mataram-Indonesia.

Woolfolk, A. (2009). Educational psychology bagian kedua edisi kesepuluh. Yogyakarta: Pustaka Pelajar.

Ya-Hui, W. (2012). A study on metacognition of college teachers. The Journal of Human Resource and Adult Learning, 8(1), 84-9.

Yang, Y. C., Newby, T. J., \& Bill, R. L. (2005). Using socratic questioning to promote critical thinking skills through asynchronous discussion forums in distance learning environments. The American Journal of Distance Education, 19(3), 163-181. 